\title{
Gender and Game Genres Differences in Playing Online Games
}

\author{
Haslina Hassan $^{1}$, Ramlah Mailok ${ }^{1}$, Mashitoh Hashim ${ }^{1}$ \\ ${ }^{I}$ Computing Department, Faculty of Arts, Computing and Creative Department, UPSI \\ \{haslina; ramlah; mashitoh\}@fskik.upsi.edu.my
}

https://doi.org/10.37134/jictie.vol6.1.2019

\begin{abstract}
Online games are currently popular among teenagers as a way to entertain their time and having fun. Some claimed that by playing games could enhance learning ability, improved focus and attention, treat depression, less anti-social and many more. However, playing games could also become an addiction where some might involve with physical and health problems. This paper investigated gender-based students' perceptions on playing games with their daily life. The perceptions study was developed based on ten items that related to students' daily task. This study is also to identify the most popular game genres and genre-gender based preference from twelve game genres listed in this study. The data were collected among 116 students from Diploma in game design and development course offered by Faculty of Arts, Computing \& Creative Industry at Sultan Idris Education University (UPSI), Malaysia. The results showed that majority of the students perceived themselves as love to play games however percentage of male students are higher than female students. The mean analyses also showed the highest score from ten (10) tasks is 'meet new friends' and this also the highest mean for both genders. The result also showed that 'Adventure' game genre is the most popular game genre among both gender while 'music/dance' genre is the least popular genre for male but the third popular game genre for female.
\end{abstract}

Keywords: games, perception, gender differences, game genres.

\section{INTRODUCTION}

Games have become one of popular entertainment and leisure activities among teenagers. They used to spend their time playing games to entertain themselves and kill time during their free hours. In today's generation of gaming, owning a game and playing games are everywhere because of easy access to online digital games. There are four common factors in games: representation, interaction, conflict, and safety. Stenros, 2015 has define a game is a closed formal system that subjectively represents a subset of reality. Differences between play and games, In play you only take your own role and attitude, in game, you take everyone's quote from Stenros, 2017. Games can be played and create to suit individual ability levels, facilitate individual study through repetition or discovery, and can simulate just about any phenomenon as whatever students want to understand. Computer games could be part of learning to be used in a classroom.(Sherry, Lucas, Greenberg, \& Holmstrom, 2013). 


\section{LITERATURE REVIEW}

Stereotype of a "gamer" known as mostly young, mostly nerdy and most definitely male, has always been stereotypically thought to vastly outnumber female gamers. Researches have consistently shown that males enjoy and play video games more than females (Dorgan, 2018; Lemmens \& Hendriks, 2016; Metzger \& Paxton, 2016; Wang \& Wang, 2008 and Lucas \& Sherry, 2004).

In a 2018 Essential facts about the computer and video game industry report by Entertainment Software Association (ESA), 2018 has reported that $45 \%$ of United Stated America (USA) gamers are women and adult women represent a greater portion of the video game-playing population (33\%) than boys under $18(17 \%)$. This show that number of female gamers continues to increase, it is beneficial to understand the motives and behaviour of gamers from both genders. To achieve this, more insight is needed into gender differences in behavioural patterns and perceptions of gamers. (Veltri, Krasnova, Baumann, \& Kalayamthanam, 2014).

In a study examining the differences in genre preferences between genders, Bonanno and Kommers, 2005 found that males tended to list strategy, sports, shooters, role playing and car racing, whereas females tended to list puzzle, adventure, fighting, managerial and car racing as their favourite genres. Wilhelm, 2018 conclude in her study that male players behave more competitively and show a stronger preference for action-oriented and role-playing genre than female players. Study by Lucas \& Sherry, 2004 that more exhaustively examined the differences between the sexes in genre preferences found statistically significant differences between males and females, with males more strongly preferring fighter, shooter, sports, racing, fantasy/role playing, action/adventure, and strategy games, and females preferring card/dice games, classic board games, quiz/trivia, puzzle, and arcade games.

\section{RESEARCH OBJECTIVES}

The research objectives are as follow:

I. To identify how UPSI Diploma in game design and development students' perceived their gaming habit and it differences between genders.

II. To identify gender based in game genres selection among UPSI Diploma in game design and development students'. 


\section{STATEMENT OF PROBLEMS}

In related to understand the interest of Diploma in design and development students in playing games and how games impact their social life, a perceptions study was conducted. This was based on assumption that as a diploma student in games design and development course they should have attained a certain level of knowledge and skills in game play and games could impact their everyday life more than others who don't. The purpose of this study is to document reported gender differences in various aspects of life tasks. By identifying these differences is important because gender is a fundamental characteristic that underlies the behaviour and societal roles of men and women. Indeed, Moreover, gender represents the most simple and, at the same time, effective variable used for targeting, presenting vast implications for marketing and learning (Veltri et al., 2014).

Research by Rehbein, Staudt, Hanslmaier and Kliem, 2016 indicates that men prefer more high-action game genres, such as shooters, sports, racing, action/adventure, and strategy, compared to women, and they are more frequent player. Moreover, data indicate that 17 of the 20 best-selling console games from 2017 were genres preferred by men (Entertainment Software Association (ESA), 2018). Taking this as supported research case study, we would like to investigate what are UPSI Diploma in game design and development students game genres preference.

\section{RESEARCH OUESTIONS}

The research questions are as follow:

I. How students perceived their gaming habits and any differences between genders among UPSI Diploma in game design and development students'?

II. What are gender differences in game genres selection among UPSI Diploma in game design and development students'?

\section{RESEARCH METHODS}

\section{Research Context and Design}

The study deployed a survey method by questionnaire for perception test. This questionnaire was used to collect user perception on how they perceive their gaming habit and their preferable type of game genres.

\section{Sampling and Data Collection}

The population of this research is the Diploma in game design and development course students at Faculty of Art, Computing and Creative Industry, Sultan Idris Education University, Malaysia. The 
size of sampling for user interpretation is 116 students which involved Semester 1 and Semester 4 students.

\section{Variable Measurement: Independent and Dependent Variables}

The independent variable used in this research is the genders of diploma students in game design and development course under department of computing. User perception ranking is used as the dependent variable. It was measured using the 4-point Likert's scale as shown in Table 1.

Table 1: Scoring in User Perceptions

\begin{tabular}{cc}
\hline Score & Level of Perception \\
\hline 1 & Strongly Disagree \\
2 & Disagree \\
3 & Agree \\
4 & Strongly Agree \\
\hline
\end{tabular}

\section{RESULTS AND DISCUSSION}

\section{Sample Profile}

The demographic profiles of respondents include gender, age, their likeness for games, device use to play games, frequent of playing games in a week, hours of playing games and preferable time to play game.

\section{Gender}

Gender profile is presented in Table 2. The gender distribution of the respondents is $64.7 \%$ males and $35.3 \%$ females.

Table 2: Gender Profile of Respondents

\begin{tabular}{cccc}
\hline Variables & & Frequency & Percentage (\%) \\
\hline Gender & Male & 75 & $64.7 \%$ \\
& Female & 41 & $35.3 \%$ \\
& Total & 116 & $100 \%$ \\
\hline
\end{tabular}

\section{Age}

The age profile of the respondents as shown in Table 3 that majority of them is between age 18 to 20 with $94.8 \%$ and age between 21 to 24 is the least with $5.2 \%$. The majorities of both genders age are 18 to 20 is $40(97.6 \%)$ and male is $70(93.3 \%)$, while age between 21 to 24 for female is 1 only $(2.4 \%)$ while male is $5(6.7 \%)$. 
Table 3: Age Profile of Respondents based on Gender

\begin{tabular}{cccccc}
\hline \multirow{2}{*}{ Variables } & \multicolumn{5}{c}{ Age } \\
\cline { 2 - 6 } & $\mathbf{1 8 - 2 0}$ & Percentage (\%) & $\mathbf{2 1 - 2 4}$ & Percentage (\%) & Total \\
\hline Female & 40 & $97.6 \%$ & 1 & $2.4 \%$ & 41 \\
Male & 70 & $93.3 \%$ & 5 & $6.7 \%$ & 75 \\
Total & 110 & $94.8 \%$ & 6 & $5.2 \%$ & 116 \\
\hline
\end{tabular}

\section{Likeness of Playing Games}

Table 4 shows the likeness of playing game. Majority students love to play game is $77(66.4 \%)$ and only $1(0.9 \%)$ dislike playing games.

Table 4: Likeness of Playing Game

\begin{tabular}{cccc}
\hline Variables & & Frequency & Percentage (\%) \\
\hline Likeness & Dislike & 1 & $0.9 \%$ \\
& Average & 38 & $32.8 \%$ \\
& Love It & 77 & $66.4 \%$ \\
& Total & 116 & $100 \%$ \\
\hline
\end{tabular}

The likeness of playing game based on gender as in Table 5 shows for majority of male students love to play games with $78.7 \%$, while for female the average is $56.1 \%$.

Table 5: Likeness of Playing Game based on Gender

\begin{tabular}{ccccccc}
\hline \multirow{2}{*}{ Variables } & \multicolumn{7}{c}{ Likeness } \\
\cline { 2 - 7 } Female & Dislike & Percentage (\%) & Average & Percentage (\%) & Love it & Percentage (\%) \\
\cline { 2 - 7 } Male & 0 & $0 \%$ & 23 & $56.1 \%$ & 18 & $43.9 \%$ \\
\hline
\end{tabular}

\section{Device Selection}

The device selection for playing game as in Table 6 shows that majority used mobile phone is $58(50 \%)$ while game console and PC share the same number, 11 respondents $(9.5 \%)$.

Table 6: Device Selection

\begin{tabular}{clcc}
\hline Variables & & Frequency & Percentage (\%) \\
\hline Likeness & Game Console & 11 & $9.5 \%$ \\
& PC & 11 & $9.5 \%$ \\
& Laptop & 31 & $26.7 \%$ \\
& Mobile Phone & 58 & $50.0 \%$ \\
& Tablet & 3 & $2.6 \%$ \\
& All of the above & 1 & $0.9 \%$ \\
& - & 1 & $0.9 \%$ \\
\hline Total & 116 & $100 \%$ \\
\hline
\end{tabular}


The device selection for playing game based on gender as in Table 7 shows that both choose mobile phone with $75.6 \%$ for female and $36 \%$ for male. However, for male, another $33.4 \%$ has chosen laptop as well.

Table 7: Device Selection based on Gender

\begin{tabular}{lcccc}
\hline \multirow{2}{*}{ Device } & \multicolumn{4}{c}{ Gender } \\
\cline { 2 - 5 } Game Console & Female & Percentage (\%) & Male & Percentage (\%) \\
\cline { 2 - 5 } PC & 2 & $4.9 \%$ & 9 & $12.0 \%$ \\
Laptop & 0 & $0 \%$ & 11 & $14.7 \%$ \\
Mobile Phone & 6 & $14.6 \%$ & 25 & $33.4 \%$ \\
Tablet & 31 & $75.6 \%$ & 27 & $36.0 \%$ \\
All of the above & 2 & $4.9 \%$ & 1 & $1.3 \%$ \\
\multicolumn{1}{c}{ Total } & 0 & $0 \%$ & 1 & $1.3 \%$ \\
\hline \multicolumn{1}{c}{} & 0 & $0 \%$ & 1 & $1.3 \%$ \\
\hline
\end{tabular}

\section{Frequent of Playing Game}

The frequent of playing game as in Table 8 shows that majority play games every day is $42(36.2 \%)$ and follow by $2-3$ times in a week with 35 respondents $(9.5 \%)$.

Table 8: Frequent of Playing Game

\begin{tabular}{llcc}
\hline Variables & & Frequency & Percentage (\%) \\
\hline Frequent & Didn't play at all & 1 & $0.9 \%$ \\
& Once a week & 18 & $15.5 \%$ \\
& 2-3 times in a week & 35 & $30.2 \%$ \\
& 4-6 times in a week & 17 & $14.7 \%$ \\
& Every day & 42 & $36.2 \%$ \\
& 2 times in a month & 1 & $0.9 \%$ \\
& When I'm bored & 1 & $0.9 \%$ \\
& If I'm in mood & 1 & $0.9 \%$ \\
& Total & 116 & $100 \%$ \\
\hline
\end{tabular}

The frequent of playing game based on gender as in Table 9 shows that for female majorities of them play 2-3 times a week is $17(41.5 \%)$ and for male majority play every day is $38(50.7 \%)$.

Table 9: Frequent of Playing Game based on Gender

\begin{tabular}{lcccc}
\hline \multirow{2}{*}{ Frequent } & \multicolumn{4}{c}{ Gender } \\
\cline { 2 - 5 } & Female & Percentage (\%) & Male & Percentage (\%) \\
\hline Didn't Play at all & 1 & $2.4 \%$ & 0 & $0 \%$ \\
Once a week & 12 & $29.3 \%$ & 6 & $8.0 \%$ \\
2-3 times in a week & 17 & $41.5 \%$ & 18 & $24.0 \%$ \\
4-6 times in a week & 6 & $14.6 \%$ & 11 & $14.7 \%$ \\
Every day & 4 & $9.8 \%$ & 38 & $50.7 \%$ \\
2 times in a month & 0 & $0 \%$ & 1 & $1.3 \%$ \\
When I'm bored & 1 & $2.4 \%$ & 0 & $0 \%$ \\
If I'm in mood & 0 & $0 \%$ & 1 & $1.3 \%$ \\
\hline Total & 41 & $100 \%$ & 75 & $100 \%$ \\
\hline
\end{tabular}




\section{Hours of Playing Game}

The hours of playing game as in Table 10 shows that majority play games $2-4$ hours is $46(39.7 \%)$ and follow by less than 2 hours with 45 respondents $(38.8 \%)$.

Table 10: Hours of Playing Game

\begin{tabular}{llcc}
\hline Variables & Frequency & Percentage (\%) \\
\hline Hours & Less than 2 & 45 & $38.8 \%$ \\
& hours & 46 & $39.7 \%$ \\
& 2-4 hours & 14 & $12.1 \%$ \\
& 5-6 hours & 10 & $8.6 \%$ \\
& More than 6 & & $100 \%$ \\
\hline & hours & 116 & \\
\hline
\end{tabular}

The frequent of playing game based on gender as in Table 11 shows female students play less than 2 hours is $26(63.4 \%)$ and for male majorities play between 2 to 4 hours is $32(42.7 \%)$.

Table 11: Hours of Playing Game based on Gender

\begin{tabular}{lcccc}
\hline \multirow{2}{*}{ Hours } & \multicolumn{4}{c}{ Gender } \\
\cline { 2 - 5 } & Female & Percentage (\%) & Male & Percentage (\%) \\
\hline Less than 2 hours & 26 & $63.4 \%$ & 19 & $25.3 \%$ \\
2-4 hours & 14 & $34.2 \%$ & 32 & $42.7 \%$ \\
5-6 hours & 1 & $2.4 \%$ & 13 & $17.3 \%$ \\
More than 6 hours & 0 & $0 \%$ & 10 & $13.3 \%$ \\
\hline Total & 41 & $100 \%$ & 75 & $100 \%$ \\
\hline
\end{tabular}

\section{Times of Playing Game}

The times of playing game as shown in Table 12, majority students play games at night is $55(47.4 \%)$ and follow by evening with 28 respondents $(24.1 \%)$.

Table 12: Time of Playing Game

\begin{tabular}{llcc}
\hline Variables & & Frequency & Percentage (\%) \\
\hline Time & Morning & 10 & $8.6 \%$ \\
& Afternoon & 4 & $3.4 \%$ \\
Evening & 28 & $24.1 \%$ \\
& Night & 55 & $47.4 \%$ \\
& Midnight (12-6AM) & 18 & $15.5 \%$ \\
& - & 1 & $0.9 \%$ \\
\hline Total & 116 & $100 \%$ \\
\hline
\end{tabular}

The frequent of playing game based on gender as in Table 13 shows that both gender play games at night is $20(48.8 \%)$ for female and male is $35(46.7 \%)$. 
Table 13: Time of Playing Game based on Gender

\begin{tabular}{lcccc}
\hline \multirow{2}{*}{ Time } & \multicolumn{4}{c}{ Gender } \\
\cline { 2 - 5 } & Female & Percentage (\%) & Male & Percentage (\%) \\
\hline Morning & 0 & $0 \%$ & 10 & $13.3 \%$ \\
Afternoon & 0 & $0 \%$ & 4 & $5.3 \%$ \\
Evening & 18 & $43.9 \%$ & 10 & $13.3 \%$ \\
Night & 20 & $48.8 \%$ & 35 & $46.7 \%$ \\
Midnight (12-6AM) & 3 & $7.3 \%$ & 15 & $20.0 \%$ \\
- & 0 & $0 \%$ & 1 & $2.4 \%$ \\
\hline Total & 41 & $100 \%$ & 75 & $100 \%$ \\
\hline
\end{tabular}

\section{Descriptive Statistics}

\section{Research Question No. 1}

How students perceived their gaming habits and any differences between genders among UPSI Diploma in game design and development students'?

To answer the research question, descriptive statistics which crosstab, mean and standard deviation is used to describe the basic of data in the study. It is to provide simple summaries on how respondents perceived games impacting their daily life based on the ten tasks.

a) Crosstab between gender and tasks

As shown in Table 14, majority of female respondents choose 'disagree' while 40 male respondents are 'agree' that they go to bed late when playing games.

Table 14: Crosstab Table Gender and Task 1: I go to bed very late

\begin{tabular}{clccccc}
\hline \multirow{4}{*}{ Gender } & & \multicolumn{4}{c}{ TASK 1: I GO TO BED VERY LATE } \\
\cline { 3 - 6 } & Female & Strongly Disagree & Disagree & Agree & Strongly Agree & Total \\
& Male & 7 & 20 & 12 & 2 & 41 \\
& Total & 7 & 20 & 40 & 7 & 74 \\
& 14 & 40 & 32 & 9 & 115 \\
\hline
\end{tabular}

As shown in Table 15, majority from both gender with 28 female respondents and 38 male respondents are 'disagree' that they forget about food when playing games.

Table 15: Crosstab Table Gender and Task 2: I forget about food

\begin{tabular}{ccccccc}
\hline \multirow{4}{*}{ Gender } & & \multicolumn{4}{c}{ TASK 2: I FORGET ABOUT FOOD } \\
\cline { 3 - 7 } & Female & Strongly Disagree & Disagree & Agree & Strongly Agree & Total \\
& Male & 7 & 28 & 5 & 0 & 40 \\
& Total & 21 & 38 & 16 & 0 & 75 \\
& 28 & 66 & 21 & 0 & 115 \\
\hline
\end{tabular}


As shown in Table 16, a majority of 19 female respondents are 'strongly disagree' and 'disagree' while 41 male respondents are 'disagree' that they ignore their course assignment when playing games.

Table 16: Crosstab Table Gender and Task 3: I ignore my course assignment

\begin{tabular}{clccccc}
\hline \multirow{5}{*}{ Gender } & & \multicolumn{5}{c}{ TASK 3: I IGNORE MY COURSE ASSIGNMENT } \\
\cline { 3 - 6 } & Female & Strongly Disagree & Disagree & Agree & Strongly Agree & Total \\
& Male & 19 & 19 & 2 & 1 & 41 \\
& Total & 29 & 41 & 3 & 0 & 73 \\
& 48 & 60 & 5 & 1 & 114 \\
\hline
\end{tabular}

As shown in Table 17, a majority of 20 female respondents are 'strongly disagree' while 30 male respondents 'are disagree' that they delay their Solat/pray time when playing games.

Table 17: Crosstab Table Gender and Task 4: I delay my Solat/Pray time

\begin{tabular}{llccccc}
\hline \multirow{4}{*}{ Gender } & & \multicolumn{5}{c}{ TASK 4: I DELAY MY SOLAT/PRAY TIME } \\
\cline { 3 - 6 } & Female & Strongly Disagree & Disagree & Agree & Strongly Agree & Total \\
& Male & 20 & 16 & 4 & 0 & 40 \\
& Total & 24 & 30 & 17 & 1 & 72 \\
& 44 & 46 & 21 & 1 & 112 \\
\hline
\end{tabular}

As shown in Table 18, a majority of 26 female respondents are 'strongly disagree' while 38 male respondents are 'disagree' that they miss their classes when playing games.

Table 18: Crosstab Table Gender and Task 5: I miss my classes

\begin{tabular}{clccccc}
\hline \multirow{5}{*}{ Gender } & & \multicolumn{5}{c}{ TASK 5: I MISS MY CLASSES } \\
\cline { 3 - 6 } & Female & Strongly Disagree & Disagree & Agree & Strongly Agree & Total \\
& Male & 26 & 11 & 3 & 0 & 40 \\
& Total & 33 & 38 & 2 & 1 & 74 \\
& 59 & 49 & 5 & 1 & 114 \\
\hline
\end{tabular}

As shown in Table 19, a majority of 15 female respondents are 'strongly disagree' while 36 male respondents are 'disagree' that they ignore people around them when playing games.

Table 19: Crosstab Table Gender and Task 6: I ignore people around me

\begin{tabular}{clccccc}
\hline \multirow{4}{*}{ Gender } & & \multicolumn{5}{c}{ TASK 6: I IGNORE PEOPE AROUND ME } \\
\cline { 3 - 6 } & Female & Strongly Disagree & Disagree & Agree & Strongly Agree & Total \\
& Male & 15 & 14 & 12 & 0 & 41 \\
& Total & 19 & 36 & 18 & 1 & 74 \\
& 34 & 50 & 30 & 1 & 115 \\
\hline
\end{tabular}


As shown in Table 20, a majority of 18 female respondents are 'disagree' while 30 male respondents are 'agree' that they don't mind spending on games when playing games.

Table 20: Crosstab Table Gender and Task 7: I don't mind spending on games

\begin{tabular}{ccccccc}
\hline & & \multicolumn{4}{c}{ TASK 7: I DON'T MIND SPENDING ON GAMES } \\
\cline { 3 - 7 } Gender & Strongly Disagree & Disagree & Agree & Strongly Agree & Total \\
& Female & 14 & 18 & 7 & 2 & 41 \\
& Male & 8 & 29 & 33 & 2 & 72 \\
& Total & 22 & 47 & 40 & 4 & 113 \\
\hline
\end{tabular}

As shown in Table 21, a majority from both gender with 25 female and 48 male respondents 'agree' that they meet new friends when playing games.

Table 21: Crosstab Table Gender and Task 8: I meet new friends

\begin{tabular}{ccccccc}
\hline \multirow{4}{*}{ Gender } & & \multicolumn{4}{c}{ TASK 8: I MEET NEW FRIENDS } \\
\cline { 3 - 7 } & Female & Strongly Disagree & Disagree & Agree & Strongly Agree & Total \\
& Male & 7 & 5 & 25 & 4 & 41 \\
& Total & 7 & 8 & 48 & 12 & 75 \\
& 14 & 13 & 73 & 16 & 116 \\
\hline
\end{tabular}

As shown in Table 22, a majority of 14 female respondents are 'disagree' and 14 'agree' while 52 male respondents 'agree' that they know the strategy/cheat to win when playing games.

Table 22: Crosstab Table Gender and Task 9: I know the strategy/cheat to win

\begin{tabular}{clccccc}
\hline \multirow{5}{*}{ Gender } & & \multicolumn{4}{c}{ TASK 9: I KNOW THE STRATEGY/CHEAT TO WIN } \\
\cline { 3 - 7 } & Female & Strongly Disagree & Disagree & Agree & Strongly Agree & Total \\
& Male & 6 & 14 & 14 & 7 & 41 \\
& Total & 5 & 11 & 52 & 6 & 74 \\
& 11 & 25 & 66 & 13 & 115 \\
\hline
\end{tabular}

As shown in Table 23, a majority of 14 female respondents are 'disagree' while 31 male respondents are 'disagree' and 30 are 'agree' that they do not want to stop when playing games.

Table 23: Crosstab Table Gender and Task 10: I don't want to stop

\begin{tabular}{ccccccc}
\hline & & \multicolumn{4}{c}{ TASK 10: I DON'T WANT TO STOP } \\
\cline { 3 - 7 } Gender & Strongly Disagree & Disagree & Agree & Strongly Agree & Total \\
& Female & 14 & 15 & 9 & 2 & 40 \\
& Male & 9 & 31 & 30 & 4 & 74 \\
& Total & 23 & 46 & 39 & 6 & 114 \\
\hline
\end{tabular}




\section{b) Mean and Standard Deviation}

Table 24 shows overall mean and standard deviation (SD) for ten items of daily tasks as a student. It shows that item 'I meet new friends' has the highest mean at 2.78 with 0.832 standard deviation (SD), follow by item 'I know the strategy/cheat to win' at mean $2.70(0.794 \mathrm{SD})$ and item 'I got to bed very late' at mean 2.49 ( $0.810 \mathrm{SD})$. The lowest mean is item 'I miss my classes at 1.54 (0.626 $\mathrm{SD})$.

Table 24: Mean, Median, Mode and Standard Deviation of 10 Tasks Item

\begin{tabular}{|c|c|c|c|c|c|}
\hline No & $\begin{array}{l}\text { Item (Task): } \\
\text { When Playing Games... }\end{array}$ & Mean & Median & Mode & SD \\
\hline 1 & I go to bed very late & 2.49 & 3.00 & 3 & 0.810 \\
\hline 2 & I forget about food & 1.94 & 2.00 & 2 & 0.653 \\
\hline 3 & I ignore my course assignments & 1.64 & 2.00 & 2 & 0.612 \\
\hline 4 & I delay my Solat /pray time & 1.81 & 2.00 & 2 & 0.766 \\
\hline 5 & I miss my classes & 1.54 & 1.00 & 1 & 0.626 \\
\hline 6 & I ignore other people around me & 1.98 & 2.00 & 2 & 0.772 \\
\hline 7 & I don't mind spending on games & 2.23 & 2.00 & 2 & 0.802 \\
\hline 8 & I meet new friends & 2.78 & 3.00 & 3 & 0.832 \\
\hline 9 & I know the strategy/cheat to win & 2.70 & 3.00 & 3 & 0.794 \\
\hline 10 & I don't want to stop & 2.25 & 2.00 & 2 & 0.837 \\
\hline
\end{tabular}

Table 25 shows mean and standard deviation for each ten items of daily task as a student based on gender differences. Both genders have highest mean on the item 'I meet new friends' at 2.63 (0.888SD) and $2.87(0.794 \mathrm{SD})$ and follow by mean for item 'I know the strategy/cheat to win' at $2.54(0.951 \mathrm{SD})$ and $2.80(0.682 \mathrm{SD})$. The lowest mean for each gender is the item 'I miss my classes' at $1.43(0.636 \mathrm{SD})$ and $1.61(0.615 \mathrm{SD})$.

Table 25: Mean and Standard Deviation of 10 Items based on Gender

\begin{tabular}{clcccc}
\hline \multirow{2}{*}{ No } & Item (Task): & \multicolumn{3}{c}{ Female } & \multicolumn{2}{c}{ Male } \\
\cline { 2 - 5 } & When Playing Games... & Mean & SD & Mean & SD \\
\hline 1 & I go to bed very late & 2.22 & 0.791 & 2.64 & 0.786 \\
2 & I forget about food & 1.95 & 0.552 & 1.93 & 0.704 \\
3 & I ignore my course assignments & 1.63 & 0.698 & 1.64 & 0.562 \\
4 & I delay my Solat /pray time & 1.60 & 0.672 & 1.93 & 0.793 \\
5 & I miss my classes & 1.43 & 0.636 & 1.61 & 0.615 \\
6 & I ignore other people around me & 1.93 & 0.818 & 2.01 & 0.749 \\
7 & I don't mind spending on games & 1.93 & 0.848 & 2.40 & 0.725 \\
8 & I meet new friends & 2.63 & 0.888 & 2.87 & 0.794 \\
9 & I know the strategy/cheat to win & 2.54 & 0.951 & 2.80 & 0.682 \\
10 & I don't want to stop & 1.98 & 0.891 & 2.39 & 0.773 \\
\hline
\end{tabular}




\section{Research Question No.2}

What are gender differences in game genres selection among UPSI Diploma in game design and development students'?

To answer this research question, descriptive statistics is used to describe the frequencies selection of games genres based on gender. The selection game genres for this study are adventure, board/card, puzzle, platform, strategy, sport, action, shooting, simulation, Role-Playing Games (RPG), music/dance and cross genre.

\section{a) Game Genres versus Gender}

As shown in Table 27, the most popular game genres selection is 'Adventure' with $71.6 \%$ follow by 'Strategy' with $69.8 \%$ and 'Action' with $68.1 \%$. The lowest game genres selection is 'Cross Genre' with $32.8 \%$.

Based on gender, the most popular game genres selections for female which share the same percentages of $63.4 \%$ are 'Adventure' and 'Puzzle'. The second most popular is 'Shooting' genre with $58.5 \%$ and third most popular are 'Strategy' and 'Music/Dance' genre which share the same percentages at $56.1 \%$. The least popular genre for female is 'Cross Genre' at $22 \%$.

Furthermore, the most popular game genres selections for male which also share the same percentages of $77.3 \%$ are 'Strategy' and 'Action' genres. The second most popular is 'Adventures' genre with $76 \%$ and follow by 'Shooting' genre with $68 \%$. The least popular game genre for male is 'Music/Dance' genre with $38.7 \%$.

Table 27: Game Genres Selection based on Gender

\begin{tabular}{|c|l|c|c|c|c|c|c|}
\hline No & Game Genres & Female & Percentages (\%) & Male & Percentages (\%) & Total & Percentages (\%) \\
\hline 1 & Adventure & 26 & 63.4 & 57 & 76.0 & 83 & 71.6 \\
\hline 2 & Board/card & 17 & 41.5 & 27 & 36.0 & 44 & 37.9 \\
\hline 3 & Puzzle & 26 & 63.4 & 27 & 36.0 & 53 & 45.7 \\
\hline 4 & Platform & 20 & 48.8 & 34 & 45.3 & 54 & 46.6 \\
\hline 5 & Strategy & 23 & 56.1 & 58 & 77.3 & 81 & 69.8 \\
\hline 6 & Sport & 15 & 36.6 & 42 & 56.0 & 57 & 49.1 \\
\hline 7 & Action & 21 & 51.2 & 58 & 77.3 & 79 & 68.1 \\
\hline 8 & Shooting & 24 & 58.5 & 51 & 68.0 & 74 & 64.7 \\
\hline 9 & Simulation & 15 & 36.6 & 30 & 40 & 45 & 38.8 \\
\hline 10 & RPG & 10 & 24.4 & 42 & 56.0 & 52 & 44.8 \\
\hline 11 & Music/Dance & 23 & 56.1 & 22 & 29.3 & 45 & 38.8 \\
\hline 12 & Cross Genre & 9 & 22.0 & 29 & 38.7 & 38 & 32.8 \\
\hline
\end{tabular}




\section{DISCUSSION}

\section{Research Question No.1}

How students perceived their gaming habits and any differences between genders among UPSI Diploma in game design and development students'?

The first research question revealed a statistically based from means data that both genders agree that they meet new friends while playing games and they know the strategy or cheat to win the game. This show that games could help them to socialise with people and plan their own strategy or find ways to win the games. This finding is also supported by (Entertainment Software Association (ESA), 2018) report that $55 \%$ of the most frequent gamers in USA say that video games help them connect with friends. Looking at the lowest mean, we identified that both genders also disagree that they would miss their classes when they playing games, this follow by not ignoring their course assignment for male respondents and not delaying Solat/Pray time by female respondents. This shows that both genders perceived themselves of not ignoring task that related to their duty as a student and know their responsibility toward their religion.

\section{Research Question No.2}

What are gender differences in game genres selection among UPSI Diploma in game design and development students'?

The second research question revealed that 'Adventure' genre is the most popular game genres selection by respondents. However based from (Entertainment Software Association (ESA), 2018) report, the most best-selling video games super genre of 2017 is Shooters (25.9\%) follow by Action (21.9\%) and Role Playing (11.3\%), while 'Adventure' genre was sold at 9.1\% from the total purchased.

However, both genders have different most popular game genres selections. In case of female respondents, they had selected 'Adventure' as their most preferable game genres as well as 'Puzzle' genre. These showed that girls prefer adventure and puzzle games at the same time. The least popular game genre for female is 'Cross Genre' which is the type of games taking the best of other games and putting them together to create a new experience. For male respondents, there are two game genres that they had selected with the same percentages which are 'Strategy' and 'Action' genres. These showed that boys as well prefer strategy and action games at the same time and are synchronies with the ESA 2018 report. 'Music/Dance' genre is the least preferable game genre for boys but is the third preferable game genre for girls. 


\section{CONCLUSION}

This study has given us some insight on how students perceived games with their life as a student. The investigation has shown that both genders agree that games did have positive effects on socialising and learn how to strategize their game plan. This also raises number of specific issues with student attitudes and behaviour in playing games. Before this study was conducted, some instructors and lecturers had identified most of their students playing games at night which made them slept late and contribute to late arrival to class the next day. However, from the analyses, we identified that most students claim to agree that they did slept late but disagree that they came late to class. A further investigation on this expects could be suggested as a future research.

Since schools in Malaysia are already well down the road of using ICT in teaching and learning as well as gamification, student need more time and support to acquire greater competence in a broad range of applications and learning style in order to extend into competitive world of technology today. The study also emphasized in finding about the relevance and benefits from games as an engagement and motivation factors. This possibility provides a general view of student's behaviour toward game and how it would affect their focus in the classroom and evaluate it for improvement in learning.

With this in mind, since majority of schools and IHEs in Malaysia are using ICT for teaching and learning in class, it is importance as a learner to be actively engage in learning ( Venkatesh, Croteau, \& Rabah, 2014). Taking Sultan Idris Education University (UPSI) as our case study, gamification, game-based learning and challenge-based learning have been introduced as part delivering and conducting teaching and learning process. As blended learning is part of UPSI teaching and learning environment, this process is making useful contribution to learning in many diverse ways. With seven smart existing smart classrooms in UPSI which some of it has include games applications and software and hardware sets, learning should be more effective and fun. The issue is how to find the best tools or applications and how to match them to teaching and learning style to develop, for example, independent learning and metacognitive awareness.

Currently, in Indonesia we can see so much influence of technological progress towards cultural values in the embrace of society, both urban and rural (modernization). Technological advances such as television, telephones and mobile phones (HP) or so-called gadgets, not only hit the urban community but also have been enjoyed by people in remote villages. As a result, any information that is both positive and negative can easily be accessed by the public. And in admit or not, slowly start to change the pattern of life and thought patterns of people, especially rural communities with all the image that became their trademark. This situation has influenced people's lifestyles and mindsets, especially among teenagers. 


\section{REFERENCES}

Bonanno, P., \& Kommers, P. A. M. (2005). Gender differences and styles in the use of digital games. Educational Psychology (vol. 25). http://doi.org/10.1080/0144341042000294877

Dorgan, T. (2018). Video game engagement: gender differences, preferred mode of play and problem solving. Dublin Business School, School of Arts, Dublin. Retrieved from https://esource.dbs.ie/bitstream/handle/10788/3421/ba_dorgan_t_2018.pdf?sequence=1\&isAllowed=y

Entertainment Software Association (ESA). (2018). 2018 Essential Facts about the computer and video game industry. Retrieved from http://www.theesa.com/wp-content/uploads/2018/05/EF2018_FINAL.pdf

Lemmens, J. S., \& Hendriks, S. J. F. (2016). Addictive Online Games: Examining the Relationship Between Game Genres and Internet Gaming Disorder. Cyberpsychology, Behavior, and Social Networking, 19(4), 270-276. http://doi.org/10.1089/cyber.2015.0415

Lucas, K., \& Sherry, J. L. (2004). Sex differences in video game play: A communication-based explanation. Communication Research, 31(5), 499-523. http://doi.org/10.1177/0093650204267930

Metzger, S. A., \& Paxton, R. J. (2016). Gaming History: A Framework for What Video Games Teach About the Past. Theory and Research in Social Education, 44(4), 532-564. http://doi.org/10.1080/00933104.2016.1208596

Rehbein, F., Staudt, A., Hanslmaier, M., \& Kliem, S. (2016). Video game playing in the general adult population of Germany: Can higher gaming time of males be explained by gender specific genre preferences? Computers in Human Behavior, 55 , 729-735. http://doi.org/10.1016/j.chb.2015.10.016

Sherry, J. L., Lucas, K., Greenberg, B. S., \& Holmstrom, A. (2013). Child Development and Genre Preference: Research for Educational Game Design. Cyberpsychology, Behavior, and Social Networking, 16(5), 335-339. http://doi.org/10.1089/cyber.2012.0242

Stenros, J. (2015). Playfulness, Play, and Games. Finland: Taylor.

Stenros, J. (2017). The Game Definition Game : A Review. Games and Culture : A Journal of Interactive Media, 12(6), 499520. http://doi.org/10.1177/1555412016655679

Veltri, N. F., Krasnova, H., Baumann, A., \& Kalayamthanam, N. (2014). Gender Differences in Online Gaming: A Literature Review. Twentieth Americas Conference on Information Systems, 1-11. Retrieved from https://aisel.aisnet.org/cgi/viewcontent.cgi?article=1231\&context=amcis2014

Venkatesh, V., Croteau, A.-M., \& Rabah, J. (2014). Perceptions of Effectiveness of Instructional Uses of Technology in Higher Education in an Era of Web 2.0. Paper presented at the IEEE 47th Hawaii International Conference on System Sciences. http://doi.org/10.1109/HICSS.2014.22

Wang, H. Y., \& Wang, Y. S. (2008). Gender differences in the perception and acceptance of online games. British Journal of Educational Technology, 39(5), 787-806. http://doi.org/10.1111/j.1467-8535.2007.00773.x

Wilhelm, C. (2018). Gender role orientation and gaming behavior revisited: examining mediated and moderated effects. Information Communication and Society, 21(2), 224-240. http://doi.org/10.1080/1369118X.2016.1271902 